\title{
Staphylococcus pasteuri sp. nov., Isolated from Human, Animal, and Food Specimens
}

\author{
O. CHESNEAU, ${ }^{1}$ A. MORVAN, ${ }^{1}$ F. GRIMONT, ${ }^{2}$ H. LABISCHINSKI, ${ }^{3}$ AND N. EL SOLH ${ }^{1 *}$ \\ National Reference Center for Staphylococci, Laboratoire des Staphylocoques et des Streptocoques, ${ }^{1}$ and \\ Unité des Entérobactéries, U199 Institut National de la Santé et de la Recherche Médicale, ${ }^{2}$ Institut \\ Pasteur, 75724 Paris Cedex 15, France, and Abteilung für Cytologie, Robert Koch-Institut \\ des Bundesgesundheitsamts, Nordufer 20, D-1000 Berlin 65, Germany ${ }^{3}$
}

\begin{abstract}
A new novobiocin-susceptible species of the genus Staphylococcus, Staphylococcus pasteuri, is described on the basis of the results of a study of seven strains isolated from human, animal, and food specimens. DNA relatedness experiments (S1 nuclease method) showed that these strains form a homogeneous genomic species related at DNA homology levels of 2 to $13 \%$ to 27 type strains representing known Staphylococcus species. The use of a method based on rRNA gene restriction site polymorphism provides clear-cut distinction between this new species and Staphylococcus warneri, which is the most similar species phenotypically. The type strain of the new species is strain BM9357 (= ATCC 51129).
\end{abstract}

Taxonomy of the genus Staphylococcus was shaken by two important methodological steps: an extensive phenotypic investigation of human strains which led to the delineation of 10 species in $1975(22,32)$ and DNA relatedness studies which have currently circumscribed 29 species $(15$, $17,19,23,31,36)$ and four named subspecies $(3,9,20,25)$.

We have recently developed a method based on rRNA gene restriction site polymorphism for identifying Staphylococcus species and subspecies $(4,7,8,12)$. The use of this method enabled the screening of seven staphylococcal strains, isolated from various sources (human, animal, and food specimens), that were phenotypically similar to Staphylococcus warneri but genotypically more closely related to each other than to any of the 271 strains validly classified as belonging to 31 staphylococcal taxa $(7,8)$. In the present study, DNA-DNA hybridization experiments grouped these seven strains into a new species, Staphylococcus pasteuri, described in this paper.

\section{MATERIALS AND METHODS}

Bacterial strains. Seven epidemiologically unrelated isolates were recovered from human clinical specimens (BM9357 ${ }^{\mathrm{T}}$ [T = type strain] from vomit; BM9363 from urine; BM10425, BM10426, and BM10427 from hemocultures), mixed vegetables (BM9359), and goat's milk (BM10507). A loopful of each sample was streaked onto a nutrient sheep blood agar plate, and the plates were incubated for $24 \mathrm{~h}$ at $37^{\circ} \mathrm{C}$. The medium used for propagation of all isolates was brain heart infusion (Difco Laboratories, Detroit, Mich.). All cultures were stored as frozen suspensions at $-20^{\circ} \mathrm{C}$ in brain heart infusion containing 30\% (vol/vol) glycerol (Prolabo, Paris, France). The type strains of 27 Staphylococcus species (Table 1) were purchased from the following institutions: American Type Culture Collection, Rockville, Md., National Collection of Type Cultures, London, England, Deutsche Sammlung von Mikroorganismen, Braunschweig, Germany, and Czechoslovak Collection of Microorganisms, J. E. Purkyne University, Brno, Czechoslovakia. The three Staphylococcus hominis strains and the nine $S$. warneri strains (Table 2), collected by the French National Refer-

\footnotetext{
* Corresponding author.
}

ence Center for Staphylococci (Institut Pasteur, Paris, France), were previously identified by our method based on rRNA gene restriction site polymorphism $(4,8)$.

Phenotypic characterization. To observe daily morphology and pigmentation of colonies, bacterial strains were grown on $\mathrm{P}$ agar (24) and $\mathrm{P}$ agar containing $1.7 \%$ (vol/vol) skim milk at $35^{\circ} \mathrm{C}$ for 3 days and at $25^{\circ} \mathrm{C}$ for an additional 2 days $(21$, 23). Cell morphology was observed with Gram-stained smears. Growth at various temperatures and salt tolerance were evaluated after incubation for $48 \mathrm{~h}$ (24). Anaerobic growth was tested by using a semisolid Brewer thioglycolate medium (Difco) (13). The configuration of lactic acid produced from glucose under anaerobic conditions (33) was analyzed enzymatically with a commercial kit (Boehringer Mannheim GmbH, Mannheim, Germany). Catalase activity was tested by inoculating a small amount of a plate culture into a drop of $3 \% \mathrm{H}_{2} \mathrm{O}_{2}$. Free coagulase and clumping factor were detected by using the Staphylocoagulase test with rabbit plasma (Diagnostics Pasteur, Marnes-la-Coquette, France) and the Staphyslide test (BioMérieux, Marcy l'Etoile, France), respectively. The following characteristics were determined as previously described: fibrinolysin activity (5) tested with rabbit plasma, oxidase activity (14), DNase activity (26), $\beta$-glucosidase activity (37), caseinolytic activity $(10)$, and nitrate reduction and acid production aerobically from various carbohydrates (24). Hemolysis was tested on tryptic soy agar (Difco) containing 5\% (vol/vol) washed sheep erythrocytes (Diagnostics Pasteur), and the hemolysins produced were characterized by their synergy with $\beta$-toxin, using the CAMP disk procedure (18). Gelatin hydrolysis and egg yolk reaction were detected in tryptic soy agar supplemented with $0.5 \%$ (wt/vol) gelatin (Merck, Darmstadt, Germany) and 5\% (vol/vol) egg yolk emulsion, respectively (35). Esculin hydrolysis was detected by using an ID32 Staph gallery (API BioMérieux, La Balme les Grottes, Montalieu-Vercieu, France), as were the activities of the following enzymes: $\beta$-galactosidase, $\beta$-glucuronidase, pyrrolidonyl arylamidase, arginine arylamidase, and $N$-acetylglucosaminidase. Determination of acetoin production in Clark and Lubs' liquid medium (Diagnostics Pasteur), detection of urease activity on Christensen urea agar (Diagnostics Pasteur), and detection of arginine dihydrolase and ornithine decarboxylase activities in Moeller's liquid media (Diagnos- 
TABLE 1. DNA relatedness between $S$. pasteuri and 27 Staphylococcus species

Source of unlabeled DNA ${ }^{a}$

$\%$ Reassociation at $60^{\circ} \mathrm{C}$ with labeled DNA from $\mathrm{BM} 9357^{\mathrm{T}}$

S. pasteuri BM9357 $7^{\mathrm{T}}$

100

S. pasteuri BM9359

S. pasteuri BM9363

S. pasteuri BM10507.. 93 98 94

S. arlettae DSM $20672^{\mathrm{T}}$

S. aureus ATCC $12600^{\mathrm{T}}$.

S. auricularis ATCC $33753^{\mathrm{T}}$

S. capitis ATCC $27840^{\mathrm{T}}$

S. caprae CCM $3573^{\mathrm{T}}$.

S. carnosus DSM $20501^{\mathrm{T}}$.

S. caseolyticus ATCC $13548^{\mathrm{T}}$

S. chromogenes NCTC $10530^{\mathrm{T}}$

S. cohnii ATCC $29974^{\mathrm{T}}$

$S$. delphini ATCC $49171^{\mathrm{T}}$

S. epidermidis ATCC $14990^{\mathrm{T}}$.

S. equorum DSM $20674^{\mathrm{T}}$

S. felis ATCC $49168^{\mathrm{T}}$.

S. gallinarum CCM $3572^{\mathrm{T}}$

S. haemolyticus ATCC $29970^{\mathrm{T}}$

S. hominis ATCC $27844^{\mathrm{T}}$

S. hyicus ATCC $11249^{\mathrm{T}}$

S. intermedius ATCC $29663^{\mathrm{T}}$

S. kloosii DSM $20676^{\mathrm{T}}$

S. lentus ATCC $29070^{\mathrm{T}}$

S. lugdunensis ATCC $43809^{\mathrm{T}}$

(1)....

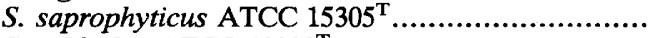

S. schleiferi ATCC $43808^{\mathrm{T}}$

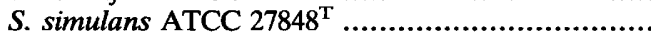

S. sciuri ATCC $29062^{\mathrm{T}}$.

S. wameri ATCC $27836^{\mathrm{T}}$

S. $x y l o s u s$ ATCC $29971^{\mathrm{T}}$

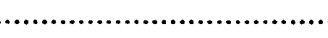

..................................

$a$ The strains whose designations begin with $\mathrm{BM}$ are from the collection of the French National Reference Center for Staphylococci (Institut Pasteur). DSM, Deutsche Sammlung von Mikroorganismen, Braunschweig, Germany; ATCC, American Type Culture Collection, Rockville, Md.; CCM, Czechoslovak Collection of Microorganisms, J. E. Purkyne University, Brno, Czechoslovakia; NCTC, National Collection of Type Cultures, London, England.

tics Pasteur) were performed according to the manufacturer's instructions.

Susceptibility to various antimicrobial agents was determined on Mueller-Hinton agar by a standard diffusion technique (1) with disks containing penicillin $G$, oxacillin, cefalotin, spectinomycin, streptomycin, kanamycin, neomycin, tobramycin, gentamicin, chloramphenicol, tetracycline, minocycline, erythromycin, oleandomycin, spiramycin, lincomycin, sulfonamides, trimethoprim, pefloxacin, fusidic acid, rifampin, fosfomycin, vancomycin, nitrofurantoin, novobiocin, and vibriostatic agent 0/129 (all obtained from Diagnostics Pasteur), as well as bacitracin (Eurobio, Les Ulis, France). Disks were prepared with pristinamycin I (40 $\mu \mathrm{g}$; Rhône-Poulenc-Rorer, Vitry-sur-Seine, France), pristinamycin II ( $20 \mu \mathrm{g}$; Rhône-Poulenc-Rorer), cadmium acetate $\mathbf{0 . 2}$ $\mu \mathrm{mol}$; Merck), sodium arseniate $(2 \mu \mathrm{mol}$; Merck $)$, mercuric nitrate $(0.2 \mu \mathrm{mol}$; Merck), ethidium bromide (200 $\mu \mathrm{g}$; Sigma Chemical Co., St. Louis, Mo.), acriflavine (200 $\mu \mathrm{g}$; Sigma), cetyltrimethylammonium bromide $(10 \mu \mathrm{g}$; International Biotechnologies, Inc., New Haven, Conn.), propamidine isothionate (200 $\mu \mathrm{g}$; May and Baker, London, England), chlorhexidine digluconate $(400 \mu g$; Coopération Pharmaceutique Française, Melun, France), lysostaphin (100 U; Sig- ma), and desferal (1 mg; Ciba-Geigy Ltd., Lane Cove, Australia).

Isolation of cell walls. Bacteria from $500 \mathrm{ml}$ of a culture grown in brain heart infusion to an optical density of 0.7 at $578 \mathrm{~nm}$ were harvested by centrifugation at $12,000 \times g$ for 10 min. After suspension in $1 \mathrm{M} \mathrm{NaCl}$, the cells were disintegrated with glass beads (diameter, $0.1 \mathrm{~mm}$; Braun, Melsungen, Germany) in a cooled cell grinder (Dyno Mill, Bachofen, Switzerland), keeping the temperature below $4^{\circ} \mathrm{C}$. After the beads were separated from the suspension with a sintered glass filter, the suspension was mixed with $250 \mathrm{ml}$ of $1 \%$ sodium dodecyl sulfate (SDS) and heated for $30 \mathrm{~min}$ at $60^{\circ} \mathrm{C}$ to remove membranes and noncovalently bound protein. After centrifugation at $12,000 \times g$ for $10 \mathrm{~min}$ and washing with distilled water (four times), covalently bound protein was removed by incubation with $0.2 \mathrm{mg}$ of trypsin (Sigma) per $\mathrm{ml}$ in $0.15 \mathrm{M}$ Tris- $\mathrm{HCl}$ buffer ( $\mathrm{pH} \mathrm{7)}$ for $24 \mathrm{~h}$. After extensive washing with buffer and distilled water, the resulting cell walls were lyophilized.

Amino acid analysis of cell walls. Samples were prepared by hydrolyzing isolated cell walls with $4 \mathrm{M} \mathrm{HCl}$ at $100^{\circ} \mathrm{C}$ for $15 \mathrm{~h}$. Amino acid analyses were performed with a model LC5001 analyzer (Biotronik, Maintal, Germany) and sodium citrate buffer. Amino acids and amino sugars were detected with the ninhydrin reagent.

Isolation of teichoic acids. Bacteria from $30 \mathrm{ml}$ of an overnight culture were harvested by centrifugation $(4,000 \times$ $g, 10 \mathrm{~min})$, washed with $\mathrm{NaCl}(0.9 \%)$, and lyophilized. The lyophilized cells were suspended in $3 \mathrm{ml}$ of $70 \%$ (wt/vol) aqueous phenol, centrifuged, and then heated for $30 \mathrm{~min}$ at $68^{\circ} \mathrm{C}$. The sediment was washed with $30 \mathrm{ml}$ of distilled water and lyophilized. Lyophilized cells $(20 \mathrm{mg})$ were treated with $40 \%$ hydrofluoric acid $\left(16 \mathrm{~h}\right.$ at $\left.4{ }^{\circ} \mathrm{C}\right)$ and centrifuged, and the supernatant was dried in vacuo. The material was dissolved in $2 \mathrm{M} \mathrm{HCl}$, hydrolyzed $\left(3 \mathrm{~h}\right.$ at $\left.100^{\circ} \mathrm{C}\right)$, and again dried in vacuo. Then several reagents were added in the following order: $300 \mu \mathrm{l}$ of dimethyl sulfoxide, $300 \mu \mathrm{l}$ of cyclohexane, $100 \mu \mathrm{l}$ of trimethylchlorosilane, and $200 \mu \mathrm{l}$ of hexamethylene disilazane. After $30 \mathrm{~min}$ at room temperature, $5 \mu \mathrm{l}$ of the upper phase was sampled for analysis.

Gas chromatography analysis of teichoic acids. We used a model 5890A gas chromatograph (Hewlett-Packard, Böblingen, Germany) equipped with an HP-5 capillary column $(0.2$ $\mu \mathrm{m}$ by $0.2 \mathrm{~mm}$ by $25 \mathrm{~m}$ ), a flame ionization detector, and a model $5898 \mathrm{~A}$ computer workstation for data registration and evaluation. Operating conditions were as follows: injection port temperature, $250^{\circ} \mathrm{C}$; detector temperature, $300^{\circ} \mathrm{C}$; carrier gas pressure, $62 \mathrm{kPa}$ (nitrogen); oven temperature programmed to increase from $100^{\circ} \mathrm{C}$ (for $1 \mathrm{~min}$ ) to $300^{\circ} \mathrm{C}$ (for 10 min) with increments of $5^{\circ} \mathrm{C} / \mathrm{min}$. Peaks were identified by comparing the retention times with retention times of standard samples.

Isolation of DNA. Large-scale preparation of cellular DNA was carried out by using $200 \mathrm{ml}$ of a culture in PY broth $(1 \%$ tryptone, $0.5 \%$ yeast extract, $0.1 \%$ glucose, $0.5 \% \mathrm{NaCl}$, $0.1 \% \mathrm{Na}_{2} \mathrm{HPO}_{4} ; \mathrm{pH} 7.2$ ). At late logarithmic growth phase, penicillin was added at a final concentration of $100 \mu \mathrm{g} \mathrm{ml}^{-1}$, and incubation was continued for $1 \mathrm{~h}$. Cells were harvested by centrifugation, washed with $0.15 \mathrm{M}$ EDTA ( $\mathrm{pH} 8)$, and resuspended in $5 \mathrm{ml}$ of TE buffer (10 $\mathrm{mM}$ Tris base [pH 8], 1 mM EDTA). They were then treated with lysozyme (40 U $\mathrm{ml}^{-1}$; Sigma) and lysostaphin (15 $\mathrm{U} \mathrm{ml}^{-1}$; Sigma) at $37^{\circ} \mathrm{C}$ until visible lysis occurred. Lysis was completed by adding $1 \%(\mathrm{wt} / \mathrm{vol})$ SDS and proteinase $\mathrm{K}\left(50 \mu \mathrm{g} \mathrm{ml}^{-1}\right.$; Merck) and leaving the cells for $30 \mathrm{~min}$ at $37^{\circ} \mathrm{C}$. Sodium chloride and cetyltrimethylammonium bromide were added at final con- 
TABLE 2 . Characteristics differentiating the 21 strains analyzed phenotypically

\begin{tabular}{|c|c|c|c|c|c|c|c|c|c|c|c|c|c|c|c|c|c|c|c|c|c|}
\hline \multirow[b]{2}{*}{ Characteristic } & \multicolumn{7}{|c|}{ S. pasteuri strains } & \multicolumn{10}{|c|}{$S$. wameri strains } & \multicolumn{4}{|c|}{ S. hominis strains } \\
\hline & 產 & 命 & 商 & $\stackrel{5}{\stackrel{5}{0}}$ & 莺 & 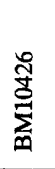 & 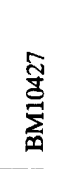 & 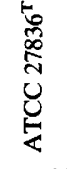 & 商 & 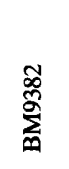 & 兮 & 莺 & 胥 & : & 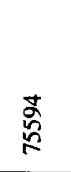 & 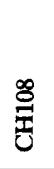 & రొ & 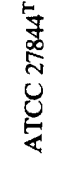 & $\sum_{n=1}^{\hat{0}}$ & ‡ั้ & $\stackrel{+}{\infty}$ \\
\hline Colony diam of $>5 \mathrm{~mm}$ & + & - & + & - & - & - & - & + & - & - & + & + & + & - & + & + & - & - & - & - & - \\
\hline Pigmentation (carotenoid) & $(+)$ & $(+)$ & $(+)$ & + & + & - & + & - & + & - & - & - & - & - & - & - & - & + & + & + & + \\
\hline $\begin{array}{l}\text { Anaerobic growth } \\
\text { (thioglycolate) }\end{array}$ & + & + & + & + & + & + & + & + & + & + & + & + & + & + & + & + & + & $\mathbf{w}$ & $\mathbf{w}$ & $\mathbf{w}$ & w \\
\hline \multicolumn{22}{|l|}{ Production of: } \\
\hline D-Lactate & + & + & + & + & + & + & + & + & + & + & + & ND & ND & ND & ND & + & + & + & ND & ND & + \\
\hline L-Lactate & + & + & + & + & + & + & + & + & + & + & + & ND & ND & ND & ND & + & + & - & ND & ND & - \\
\hline$\beta$-Glucosidase & + & + & + & + & + & + & + & + & - & + & + & - & + & + & + & + & + & - & - & + & + \\
\hline$\beta$-Glucuronidase & + & + & + & + & + & + & + & + & + & + & + & + & + & + & + & + & + & - & $\mathbf{w}$ & - & - \\
\hline Egg yolk reaction & + & + & + & + & + & + & + & - & - & + & + & - & + & + & + & - & + & - & - & - & - \\
\hline Synergistic hemolysis & + & + & + & + & + & + & + & NH & + & + & + & + & + & + & + & + & + & + & + & + & + \\
\hline Gelatin hydrolysis & + & + & - & + & + & + & + & - & + & + & + & + & - & + & - & + & + & - & - & - & - \\
\hline Nitrate reduction & - & + & + & - & + & + & + & - & + & - & + & - & + & - & + & - & - & + & - & + & + \\
\hline Acetoin production & + & + & - & + & + & + & + & + & + & + & + & + & + & + & + & + & + & - & + & + & - \\
\hline Arginine dihydrolase & + & + & - & - & + & + & $\mathbf{w}$ & + & - & + & + & - & + & + & - & + & $\mathbf{w}$ & $\mathbf{w}$ & - & - & - \\
\hline Casein hydrolysis & + & - & - & - & - & $\mathbf{w}$ & - & - & - & $\mathbf{w}$ & $\mathbf{w}$ & + & - & + & - & + & + & + & + & + & + \\
\hline$N$-Acetylglucosaminidase & - & - & $\mathbf{w}$ & - & - & - & - & - & - & - & - & - & - & - & - & - & - & - & + & - & - \\
\hline \multicolumn{22}{|l|}{$\begin{array}{l}\text { Acid produced (aero- } \\
\text { bically) from: }\end{array}$} \\
\hline D-Trehalose & + & + & + & + & + & + & + & + & + & + & + & + & - & + & + & + & + & + & + & + & + \\
\hline D-Mannose & - & - & - & - & - & - & - & $\mathbf{w}$ & - & - & - & - & - & - & - & - & + & - & - & - & - \\
\hline D-Ribose & - & - & - & - & - & - & - & + & $(+)$ & - & $(+)$ & $(+)$ & $(+)$ & $(+)$ & $(+)$ & - & - & - & - & - & - \\
\hline$\alpha$-Lactose & $(+)$ & - & - & + & - & - & - & - & - & $(+)$ & $(+)$ & - & - & $(w)$ & $\mathbf{w}$ & - & + & + & + & + & + \\
\hline Maltose & + & - & + & + & + & + & + & + & + & + & + & + & + & + & + & + & + & + & + & + & + \\
\hline D-Mannitol & + & + & - & + & + & + & + & + & + & + & - & - & - & + & - & + & + & - & - & - & - \\
\hline D-Melezitose & (w) & - & + & + & $\mathbf{w}$ & - & (w) & (w) & - & - & - & - & $(w)$ & - & (w) & - & - & (w) & $(w)$ & (w) & (w) \\
\hline D-Turanose & - & - & - & (w) & $\mathbf{w}$ & - & w & - & - & - & - & - & - & - & (w) & - & - & + & + & + & + \\
\hline $\begin{array}{l}\text { Resistance to lysostaphin } \\
(100 \mathrm{U})\end{array}$ & + & + & + & + & + & + & + & - & + & - & - & - & + & - & - & - & - & + & - & + & + \\
\hline $\begin{array}{l}\text { Resistance to desferal } \\
\text { (1 mg) }\end{array}$ & + & + & + & + & + & + & + & + & + & + & + & + & + & + & + & + & + & - & - & - & - \\
\hline
\end{tabular}

${ }^{a}+$, positive reaction; - , negative reaction; $w$, weakly positive reaction. Parentheses indicate a delayed reaction. ND, not determined; NH, nonhemolytic.

centrations of $1 \mathrm{M}$ and $1 \%$ (wt/vol), respectively, and the lysate was incubated for $10 \mathrm{~min}$ at $65^{\circ} \mathrm{C}$ prior to sequential extraction with equal volumes of phenol-chloroform-isoamyl alcohol (25/24/1, by volume) and chloroform-isoamyl alcohol (24/1, by volume) (2). Isopropanol ( 0.6 volume) was added to the last aqueous layer. Precipitated DNA was recovered by centrifugation, washed in $70 \%$ (vol/vol) ethanol, dried, resuspended in TE buffer, and treated with RNase $\left(3 \mathrm{U} \mathrm{ml}^{-1}\right.$; Boehringer) for $30 \mathrm{~min}$ at $37^{\circ} \mathrm{C}$. The purity and concentration of DNA were assayed spectrophotometrically.

rRNA gene restriction site polymorphism. Cellular DNAs isolated from the staphylococcal strains were cleaved by EcoRI (Amersham International plc, Amersham, England) and probed under stringent conditions with ${ }^{32} \mathrm{P}$-labeled plasmid pBA2 (4). The sizes of the hybridizing bands were calculated by using the Raoul I DNA ladder (Appligène, Illkirch, France) as a molecular weight standard. The hybridization patterns (HP) obtained were compared with those previously described $(7,8)$. The similarity between any two HP was assessed by calculating the Dice coefficient (11).

DNA-DNA hybridization. The S1 nuclease method (6) was used for DNA-DNA hybridization according to a procedure (the $S 1$ nuclease-trichloroacetic acid procedure) detailed elsewhere (16). Native cellular DNA was labeled in vitro by nick translation with tritium-labeled deoxynucleotides (Amersham).

DNA base composition. The guanosine-plus-cytosine $(\mathrm{G}+\mathrm{C})$ content was determined from DNA melting temperatures by the equation of Owen et al. (29). Escherichia coli K-12 DNA was included as a standard.

\section{RESULTS AND DISCUSSION}

Morphological, physiological, and biochemical characteristics. Microscopic examination of the seven $S$. pasteuri strains revealed gram-positive spherical cells, 0.5 to $1.5 \mu \mathrm{m}$ in diameter, occurring in pairs, tetrads, and irregular clusters. All strains produced catalase and were able to grow aerobically and anaerobically when incubated for $24 \mathrm{~h}$ in thioglycolate medium. They were resistant to bacitracin and vibriostatic agent $0 / 129$ but susceptible to nitrofurantoin. These properties are shared by the strains belonging to the genus Staphylococcus.

When the $S$. pasteuri strains were tested by the micromethod ID32 Staph System, the results indicated that four of them (BM9357 ${ }^{\mathrm{T}}, \mathrm{BM} 9359, \mathrm{BM} 10425$, and BM10426) could be classified as $S$. warneri, whereas the remaining three 
strains (BM9363, BM10427, and BM10507) could not be identified.

All the phenotypic tests listed in Materials and Methods and used to characterize the seven $S$. pasteuri strains were also carried out for $10 \mathrm{~S}$. warneri strains and for $4 \mathrm{~S}$. hominis strains, including the type strains of these two phenotypically related species $(21,23,37)$. The 21 staphylococcal strains analyzed had numerous properties in common including growth on agar at 15 to $45^{\circ} \mathrm{C}$ and on agar supplemented with 5 to $15 \%$ (wt/vol) sodium chloride, production of catalase and urease, acid production (aerobically) from $D$-glucose, glycerol, $\beta$-D-fructose, and sucrose, inability to hydrolyze esculin, and no production of free coagulase, clumping factor, fibrinolysin, oxidase, DNase, $\beta$-galactosidase, alkaline phosphatase, pyrrolydonyl arylamidase, arginine arylamidase, or ornithine decarboxylase or acid from $\mathrm{L}$-arabinose, D-cellobiose, $\alpha$-D-melibiose, D-raffinose, xylitol, or D-xylose. The characteristics differentiating these 21 strains are reported in Table 2. Susceptibility to desferal appeared to be the best test to discriminate the $4 \mathrm{~S}$. hominis strains from the 17 other strains belonging to $S$. pasteuri and $S$. warneri; the use of this test to distinguish $S$. hominis from $S$. warneri has been reported by Lindsay and Riley (27). Yellow pigmentation of the colonies and resistance to lysostaphin on Mueller-Hinton agar are the traits that most clearly distinguished $S$. pasteuri from $S$. warneri strains. Indeed, six of the seven $S$. pasteuri strains produced yellow pigment (better visualized on $\mathrm{P}$ agar supplemented with milk), whereas only 1 of the $10 \mathrm{~S}$. warneri strains did; the $7 S$. pasteuri strains were all resistant to lysostaphin, whereas only 2 of the $10 \mathrm{~S}$. warneri strains exhibited such resistance.

Cell wall analysis of $S$. pasteuri. All seven strains exhibited the same L-Lys-Gly ${ }_{4}$-Ser peptidoglycan type. Since the glycine/serine ratio is known to be sensitive to the composition of the culture medium, cell walls from two strains $\left(\mathrm{BM} 9357^{\mathrm{T}}\right.$ and BM10507) were also analyzed after growth in $2.5 \%$ Bacto Peptone (Difco) supplemented with $0.5 \% \mathrm{NaCl}$ and $0.5 \%$ glycine (30). However, amino acid analysis revealed no significant change in the glycine/serine ratio under

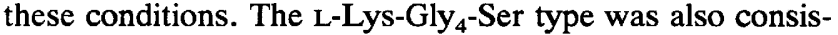
tent with the observed lysostaphin resistance of the seven $S$. pasteuri strains, since the existence of a pentaglycine interpeptide chain is a prerequisite for efficient action of this endopeptidase $(28,38)$.

Teichoic acid analysis by gas chromatography revealed the existence of the glycerol type, but not of the ribitol type, of teichoic acids in all seven $S$. pasteuri strains. $N$-acetylglucosamine was detected, by both amino acid analysis and gas chromatography, in strain BM10507, the only strain isolated from a goat. No $N$-acetylglucosamine or any other amino sugar was found in any of the other six strains. $N$-acetylglucosamine can occur among staphylococci in three structurally different types of teichoic acid (34): (i) branching from the poly(polyolphosphate) chain, (ii) forming part of the main chain of a poly(glycerolphosphateglycosylphosphate) teichoic acid, and (iii) forming the main chain of a poly(glycosylphosphate) teichoic acid. The last two types, known to occur in Staphylococcus hyicus and Staphylococcus sciuri and in Staphylococcus auricularis and Staphylococcus caseolyticus, respectively (34), are very improbable for strain BM10507 because this strain has glycerol in its teichoic acid and because the amount of $N$-acetylglucosamine detected was fairly low (approximately 2 mol per mol of muramic acid). Thus, $N$-acetylglucosamine

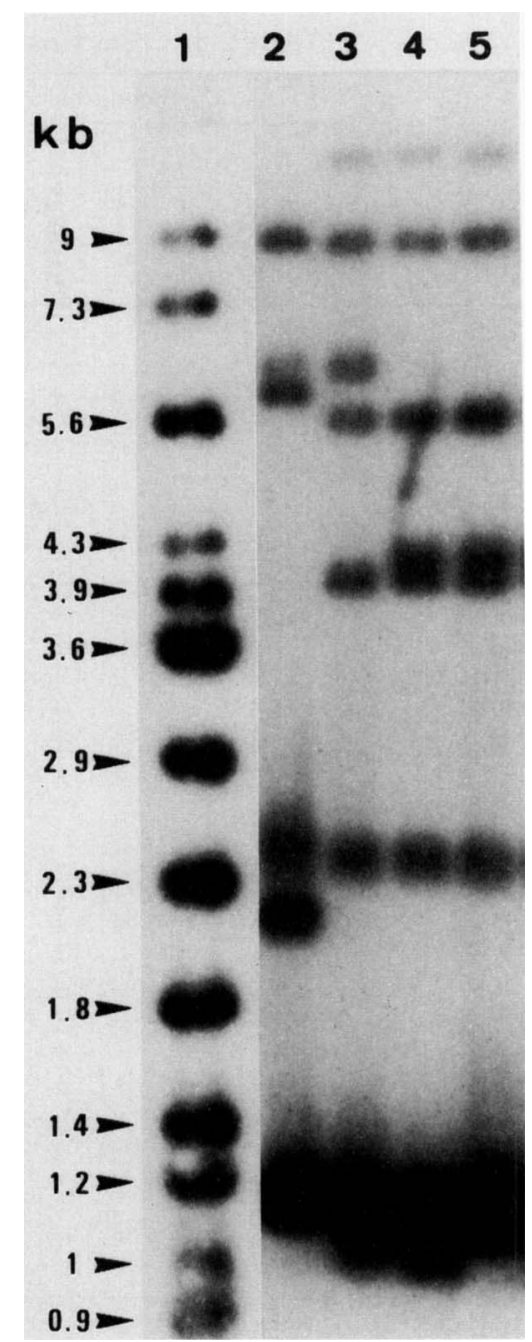

FIG. 1. EcoRI restriction patterns of $S$. pasteuri and S. warneri probed with ${ }^{32} \mathrm{P}$-labeled plasmid pBA2. Lane 1, Raoul I DNA ladder (Appligène); lane 2, S. warneri ATCC $27836^{\mathrm{T}}$ (HP E22); lane 3, S. pasteuri BM9357 ${ }^{\mathrm{T}}$ (HP E850); lane 4, S. pasteuri BM10425 (HP E851); lane 5, $S$. pasteuri BM10426 (HP E852).

appears to be a possible side chain substituent of the polyglycerolphosphate teichoic acid in $S$. pasteuri.

HP obtained with the probe pBA2 (ribosomal DNA). Three distinct HP were observed for the EcoRI-digested cellular DNAs of the seven $S$. pasteuri strains (HP E850 for BM9357 $^{\mathrm{T}}$; HP E851 for BM9359, BM10425, BM10427, and BM10507; and HP E852 for BM9363 and BM10426). As shown in Fig. 1 (lanes 3 to 5), the HP had a core of eight common hybridizing bands which are species specific, yielding an easy distinction from the single EcoRI HP, HP E22 (lane 2), detected for the $13 \mathrm{~S}$. warneri strains currently analyzed $(4,7,8)$. Each of the three HP detected for the $S$. pasteuri strains was compared with each of the 81 EcoRI HP detected for the 271 strains validly classified as belonging to 31 staphylococcal taxa $(7,8)$. The highest intertaxon percentage of similarity $(66.6 \%)$ was lower than the values calculated for the seven $S$. pasteuri strains among themselves $(84.2$ to $100 \%)$. These results suggested that the strains belonging to $S$. pasteuri were homogeneously clus- 
tered and easily distinguishable from all other staphylococcal taxa currently described. The variety of patterns observed for $S$. pasteuri strains could be used to type these strains.

Percentages of DNA-DNA homology. The DNA relatedness results obtained with labeled reference DNA from $S$. pas teuri BM9357 $7^{\mathrm{T}}$ are shown in Table 1 . The four $S$. pasteuri strains chosen for this part of the study had been recovered from distinct sources (human, animal, and food specimens) and had three distinct HP. As seen in Table 1, these four strains formed a tight genomic species since strain BM9357 ${ }^{\mathrm{T}}$ was related at levels of more than $93 \%$ to the three other $S$. pasteuri strains and at levels of no more than $13 \%$ to the 27 other staphylococcal species tested, including $S$. warneri $(\mathbf{1 1 \% )}$.

DNA base composition of $S$. pasteuri. The average base composition of each of the two $S$. pasteuri strains tested, BM9357 ${ }^{\mathrm{T}}$ and BM9363, was $35 \mathrm{~mol} \% \mathrm{G}+\mathrm{C}$. This value falls within the extreme values observed in the genus Staphylococcus (30 to $41 \mathrm{~mol} \% \mathrm{G}+\mathrm{C})(17,21)$.

Description of Staphylococcus pasteuri sp. nov. Staphylococcus pasteuri (pas' teur. i. L. gen. n. pasteuri of Pasteur, honoring the French microbiologist Louis Pasteur for his contribution in 1878 to the recognition of staphylococci as pathogenic agents and also referring to the research institute, Institut Pasteur, Paris, France, where the new species was characterized). The description of $S$. pasteuri is based on a total of seven strains isolated from different sources. The cells are nonsporulating, nonmotile, gram-positive cocci, 0.5 to $1.5 \mu \mathrm{m}$ in diameter, occurring singly, in pairs, in tetrads, or in clusters. These organisms grow on $P$ agar at 15 to $45^{\circ} \mathrm{C}$. After incubation on $\mathrm{P}$ agar at $35^{\circ} \mathrm{C}$ for 3 days and at $25^{\circ} \mathrm{C}$ for an additional 2 days, colony diameter varies from 4 to $7 \mathrm{~mm}$. The colonies are smooth, glistening, and raised with slightly elevated centers and regular edges. The yellow pigment produced by six of the seven strains is better visualized when $P$ agar is supplemented with skim milk. Growth is evident throughout a tube of thioglycolate medium and on $\mathrm{P}$ agar supplemented with 5 to $15 \%$ (wt/vol) sodium chloride. All strains produce both $\mathrm{D}$ - and L-lactate isomers from glucose under anaerobic conditions. They exhibit catalase, urease, $\beta$-glucuronidase, and $\beta$-glucosidase activities. They clear egg yolk medium and give synergistic hemolysis with $\beta$-toxin. They produce acid aerobically from D-glucose, glycerol, $\beta$-D-fructose, sucrose, and $D$-trehalose. In contrast, negative results are obtained for the following tests: free coagulase, clumping factor, fibrinolysin, oxidase, DNase, $\beta$-galactosidase, alkaline phosphatase, pyrrolidonyl arylamidase, arginine arylamidase, ornithine decarboxylase, and esculin hydrolysis. No acid is produced aerobically from L-arabinose, D-cellobiose, $\alpha$-D-melibiose, D-raffinose, xylitol, D-xylose, D-mannose, or D-ribose.

Agar disk diffusion tests show that the seven strains are resistant to lysostaphin, vibriostatic agent $0 / 129$, and bacitracin, whereas they are susceptible to oxacillin, cefalotin, spectinomycin, streptomycin, kanamycin, neomycin, tobramycin, gentamicin, minocycline, pristinamycin II, sulfonamides, trimethoprim, pefloxacin, fusidic acid, rifampin, fosfomycin, vancomycin, nitrofurantoin, novobiocin, cadmium acetate, mercuric nitrate, cetyltrimethylammonium bromide, propamidine isothionate, chlorhexidine digluconate, and desferal (Tables 2 and 3 ).

Description of the type strain. Strain BM9357 ${ }^{\mathbf{T}}$ (= ATCC $51129^{\mathrm{T}}$ ) was isolated from a vomit sample. In addition to all the characteristics shared by the seven $S$. pasteuri strains, the type strain has the following properties: gelatin and
TABLE 3. Resistance and susceptibility of $S$. pasteuri strains to various antimicrobial agents

\begin{tabular}{|c|c|c|c|c|c|c|c|}
\hline $\begin{array}{c}\text { Antibiotic } \\
\text { (load per disk) }\end{array}$ & 瓦 & 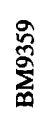 & î̀n & 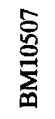 & 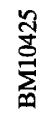 & 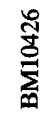 & \\
\hline Penicillin G $(6 \mu \mathrm{g})$ & $\mathbf{R}^{a}$ & $\mathbf{S}$ & $\mathbf{S}$ & $\mathbf{S}$ & $\mathbf{R}$ & $\mathbf{S}$ & \\
\hline Oxacillin $(5 \mu \mathrm{g})$ & $\mathbf{S}$ & $\mathbf{S}$ & $\mathbf{S}$ & $\mathbf{S}$ & $\mathbf{S}$ & $\mathbf{S}$ & \\
\hline Cefalotin $(30 \mu \mathrm{g})$ & S & $\mathbf{S}$ & $\mathbf{S}$ & $S$ & S & $\mathbf{S}$ & \\
\hline $\begin{array}{l}\text { Spectinomycin }(100 \mu \mathrm{g}), \text { strep- } \\
\text { tomycin }(10 \mathrm{U}), \text { kanamycin } \\
(30 \mathrm{U}), \text { neomycin }(30 \mathrm{U}), \\
\text { tobramycin }(10 \mu \mathrm{g}), \text { and } \\
\text { gentamicin }(15 \mu \mathrm{g})\end{array}$ & $\mathbf{S}$ & S & $\mathbf{S}$ & S & S & $\mathbf{S}$ & \\
\hline Chloramphenicol $(30 \mu \mathrm{g})$ & $\mathbf{S}$ & $\mathbf{S}$ & $\mathbf{S}$ & $\mathbf{R}$ & $\mathbf{S}$ & $\mathbf{S}$ & \\
\hline Tetracycline (30 U) & $\mathbf{S}$ & $\mathbf{S}$ & $\mathbf{S}$ & $\mathbf{R}$ & $\mathbf{R}$ & $S$ & \\
\hline Minocycline (30 U) & $\mathbf{S}$ & $\mathbf{S}$ & $\mathbf{S}$ & $\mathbf{S}$ & $\mathbf{S}$ & $\mathbf{S}$ & \\
\hline Erythromycin (15 U) & $S$ & $\mathbf{S}$ & $\mathbf{S}$ & $\mathbf{R}_{\mathrm{c}}$ & $\mathbf{R}_{\mathrm{c}}$ & $\mathbf{S}$ & \\
\hline Oleandomycin (15 U) & S & $\mathbf{S}$ & $S$ & $\mathbf{R}_{\mathrm{c}}$ & $\mathbf{R}_{\mathrm{c}}$ & $\mathbf{S}$ & \\
\hline Spiramycin $(100 \mu \mathrm{g})$ & $\mathbf{S}$ & $\mathbf{S}$ & $\mathbf{S}$ & $\mathbf{R}_{\mathrm{c}}$ & $\mathbf{R}_{\mathrm{c}}$ & $S$ & \\
\hline Lincomycin $(15 \mu \mathrm{g})$ & $\mathbf{S}$ & $\mathbf{S}$ & $\mathbf{S}$ & $\mathbf{R}_{\mathrm{c}}$ & $\mathbf{R}_{\mathrm{c}}$ & $\mathbf{S}$ & \\
\hline Pristinamycin I (40 $\mu \mathrm{g})$ & $\mathbf{S}$ & $\mathbf{S}$ & $\mathrm{S}$ & $\mathbf{R}_{\mathrm{c}}$ & $\mathbf{R}_{c}$ & $\mathbf{S}$ & \\
\hline Pristinamycin II $(20 \mu \mathrm{g})$ & $\mathbf{S}$ & $\mathbf{S}$ & $S$ & $\mathrm{~s}$ & $\mathrm{~s}$ & $\mathbf{S}$ & \\
\hline $\begin{array}{l}\text { Sulfonamides }(200 \mu \mathrm{g}) \text {, tri- } \\
\text { methoprim }(5 \mu \mathrm{g}), \text { pefloxacin } \\
(5 \mu \mathrm{g}) \text {, fusidic acid }(10 \mu \mathrm{g}) \text {, } \\
\text { rifampin }(30 \mu \mathrm{g}), \text { fosfomycin } \\
(50 \mu \mathrm{g}) \text {, vancomycin }(30 \mu \mathrm{g}) \text {, } \\
\text { nitrofurantoin }(300 \mu \mathrm{g}), \text { and } \\
\text { novobiocin }(5 \mu \mathrm{g})\end{array}$ & $\mathbf{S}$ & $\mathbf{S}$ & $\mathbf{S}$ & $\mathbf{S}$ & $\mathbf{S}$ & $\mathbf{s}$ & \\
\hline Bacitracin $(0.4 \mathrm{U})$ & $\mathbf{R}_{\mathrm{c}}$ & $\mathbf{R}_{\mathrm{c}}$ & $\mathbf{R}_{\mathrm{c}}$ & $\mathbf{R}_{\mathrm{c}}$ & $\mathbf{R}_{\mathrm{c}}$ & $\mathbf{R}_{\mathrm{c}}$ & $\mathbf{R}_{\mathrm{c}}$ \\
\hline $\begin{array}{l}\text { Vibriostatic agent } 0 / 129 \\
(0.5 \mathrm{mg})\end{array}$ & $\mathbf{R}_{\mathrm{c}}$ & $\mathbf{R}_{\mathrm{c}}$ & $\mathbf{R}_{\mathbf{c}}$ & $\mathbf{R}_{\mathrm{c}}$ & $\mathbf{R}_{\mathbf{c}}$ & $\mathbf{R}_{\mathrm{c}}$ & \\
\hline Cadmium acetate $(0.2 \mu \mathrm{mol})$ & $\mathbf{S}$ & $\mathbf{S}$ & $\mathbf{S}$ & $\mathbf{S}$ & $\mathbf{S}$ & $\mathbf{S}$ & \\
\hline Sodium arseniate $(2 \mu \mathrm{mol})$ & $\mathbf{R}$ & $\mathbf{R}$ & $\mathbf{R}$ & $\mathbf{R}$ & $\mathbf{R}$ & $\mathbf{S}$ & R \\
\hline Mercuric nitrate $(0.2 \mu \mathrm{mol})$ & $\mathbf{S}$ & $\mathbf{S}$ & $\mathbf{S}$ & $\mathbf{S}$ & $\mathbf{S}$ & $\mathbf{S}$ & $\mathbf{S}$ \\
\hline Ethidium bromide $(200 \mu \mathrm{g})$ & $\mathbf{S}$ & $\mathbf{S}$ & $\mathbf{S}$ & $S$ & $\mathbf{R}$ & $\mathbf{S}$ & \\
\hline Acriflavine $(200 \mu \mathrm{g})$ & $\mathbf{S}$ & $\mathbf{S}$ & $\mathbf{S}$ & $\mathbf{S}$ & $\mathbf{R}$ & $\mathbf{S}$ & \\
\hline CTAB $(10 \mu g)^{b}$ & $\mathbf{S}$ & $\mathbf{S}$ & $\mathbf{S}$ & $\mathbf{S}$ & $\mathbf{S}$ & $\mathbf{S}$ & $\mathbf{S}$ \\
\hline $\begin{array}{l}\text { Propamidine isothionate } \\
(200 \mu \mathrm{g})\end{array}$ & $\mathbf{S}$ & $\mathbf{S}$ & $\mathrm{s}$ & $\mathbf{S}$ & $\mathrm{S}$ & $\mathbf{S}$ & $\mathbf{S}$ \\
\hline $\begin{array}{l}\text { Chlorhexidine digluconate } \\
(400 \mu \mathrm{g})\end{array}$ & $\mathbf{S}$ & $\mathbf{S}$ & $\mathbf{S}$ & $\mathbf{S}$ & $\mathbf{S}$ & $\mathbf{S}$ & $\mathbf{S}$ \\
\hline
\end{tabular}

${ }^{a} R$, resistant; $S$, susceptible; $R_{c}$, resistant with growth up to the edge of the disk.

${ }^{b}$ CTAB, cetyltrimethylammonium bromide.

casein hydrolysis; acetoin production; arginine dihydrolase activity; acid production from $\alpha$-lactose, maltose, and D-mannitol; inability to reduce nitrates, to hydrolyze $\mathrm{N}$-acetylglucosamine, or to produce acid from D-melezitose or D-turanose; and resistance to penicillin $G$ by penicillinase production, to erythromycin and oleandomycin (inducible MLS phenotype), and to sodium arseniate. The $\mathrm{G}+\mathrm{C}$ content of the DNA is $37 \mathrm{~mol} \%$.

Differentiation of $S$. pasteuri from the other staphyloccocal taxa. The new species $S$. pasteuri can be phenotypically distinguished from all of the other novobiocin-susceptible staphylococcal taxa except $S$. warneri by the characteristics listed in Table 4. Although the production of yellow pigment and the resistance to lysostaphin appeared to be the best conventional tests to distinguish $S$. pasteuri from $S$. wameri (Table 2), phenotypic discrimination between these two species remains difficult since the presence or absence of these characteristics is not shared by more than $90 \%$ of the strains belonging to each taxon (Tables 2 and 4). Therefore, rRNA gene restriction site polymorphism by using plasmid pBA2 as a probe $(4,7,8,12)$ is currently the most appropri- 


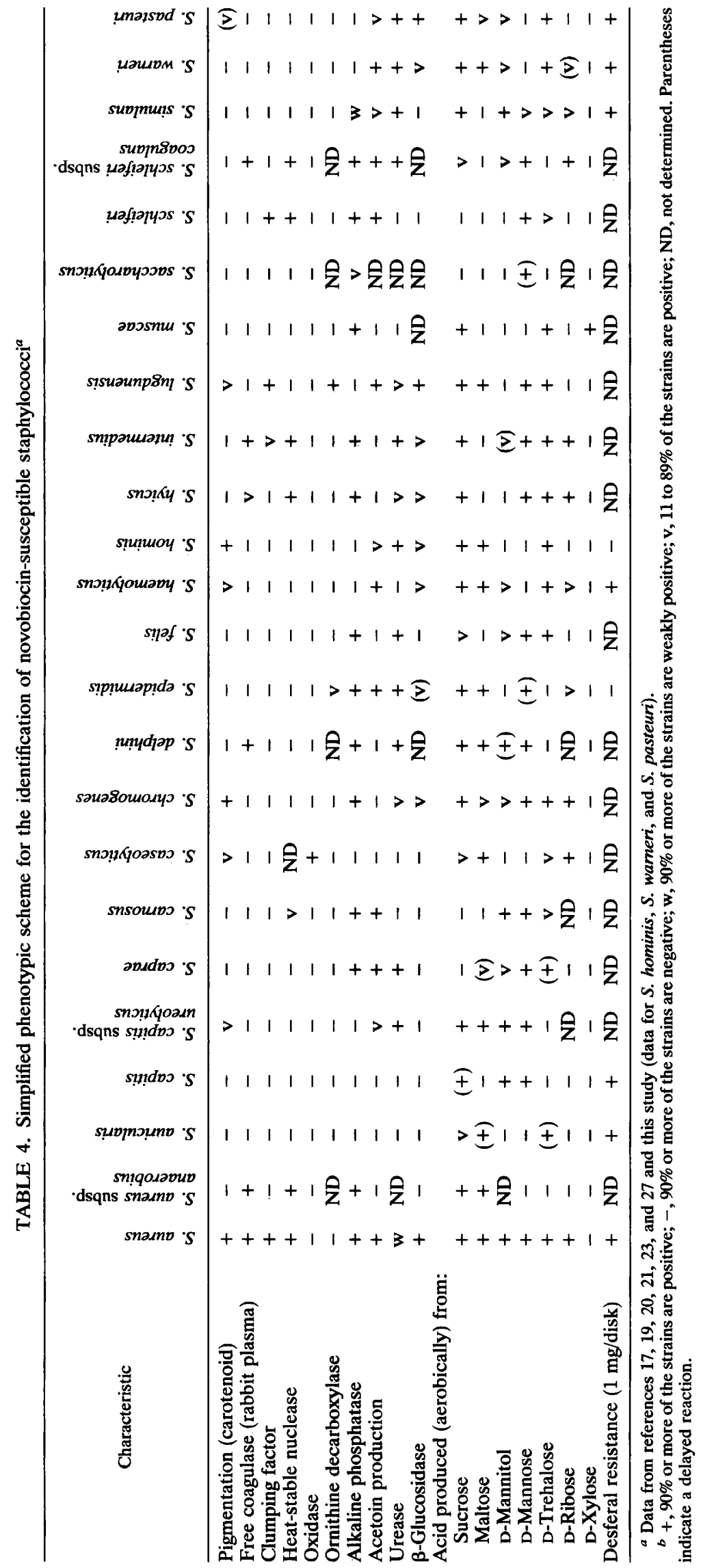


ate method to differentiate $S$. pasteuri from all of the staphylococcal taxa described previously, including $S$. warneri.

\section{ACKNOWLEDGMENTS}

We thank J. Pierre and M. L. De Buyser for providing us with four of the seven $S$. pasteuri strains, E. Ageron for technical help in DNA-DNA hybridization experiments, G. Gros, B. Reinicke, and $T$. Sidow for their contribution to the cell wall analysis, and $O$. Rouelland for secretarial assistance.

\section{REFERENCES}

1. Acar, J. F., and F. W. Goldstein. 1986. Disk susceptibility test, p. 27-63. In V. Lorian (ed.), Antibiotics in laboratory medicine. The Williams \& Wilkins Co., Baltimore.

2. Ausubel, F. M., R. Brent, R. E. Kingston, D. D. Moore, J. G. Seidman, J. A. Smith, and K. Struhl (ed.). 1987. Current protocols in molecular biology. John Wiley \& Sons, Inc., New York.

3. Bannerman, T. L., and W. E. Kloos. 1991. Staphylococcus capitis subsp. ureolyticus subsp. nov. from human skin. Int. J. Syst. Bacteriol. 41:144-147.

4. Chesneau, O., S. Aubert, A. Morvan, J. L. Guesdon, and N. El Solh. 1992. Usefulness of the ID32 Staph System and a method based on rRNA gene restriction site polymorphism analysis for species and subspecies identification of staphylococcal clinical isolates. J. Clin. Microbiol. 30:2346-2352.

5. Christie, R., and H. Wilson. 1941. A test of staphylococcal fibrinolysis. Aust. J. Exp. Biol. Med. Sci. 19:329-332.

6. Crosa, J. M., D. J. Brenner, and S. Falkow. 1973. Use of a single-strand-specific nuclease for analysis of bacterial and plasmid deoxyribonucleic acid homo- and heteroduplexes. J. Bacteriol. 115:904-911.

7. De Buyser, M. L., A. Morvan, S. Aubert, F. Dilasser, and N. El Solh. 1992. Evaluation of a ribosomal RNA gene probe for the identification of species and subspecies within the genus Staphylococcus. J. Gen. Microbiol. 138:889-899.

8. De Buyser, M. L., A. Morvan, F. Grimont, and N. El Solh. 1989. Characterization of Staphylococcus species by ribosomal RNA gene restriction patterns. J. Gen. Microbiol. 135:989-999.

9. De La Fuente, R., G. Suarez, and K. H. Schleifer. 1985. Staphylococcus aureus subsp. anaerobius subsp. nov., the causal agent of abscess disease of sheep. Int. J. Syst. Bacteriol. 35:99-102.

10. Devriese, L. A. 1979. Identification of clumping factor negative staphylococci isolated from cows' udders. Res. Vet. Sci. 27: 313-320.

11. Dice, L. R. 1945. Measures of the amount of ecologic association between species. Ecology 26:297-302.

12. El Solh, N., M. L. De Buyser, A. Morvan, F. Grimont, S. Walcher-Salesse, S. Aubert, C. Monzon-Moreno, O. Chesneau, and J. Allignet. 1990. Use of Bacillus subtilis 16S rRNA genes as a probe to identify species, subspecies, and types in the genus Staphylococcus, p. 585-593. In R. P. Novick (ed.), Molecular biology of the staphylococci. VCH Publishers, Inc., New York.

13. Evans, J. B., and W. E. Kloos. 1972. Use of shake cultures in a semisolid thioglycolate medium for differentiating staphylococci from micrococci. Appl. Microbiol. 23:326-331.

14. Faller, A., and K. H. Schleifer. 1981. Modified oxidase and benzidine tests for separation of staphylococci. J. Clin. Microbiol. 13:1031-1035.

15. Freney, J., Y. Brun, M. Bes, H. Meugnier, F. Grimont, P. A. D. Grimont, C. Nervi, and J. Fleurette. 1988. Staphylococcus lugdunensis sp. nov. and Staphylococcus schleiferi sp. nov., two species from human clinical specimens. Int. J. Syst. Bacteriol. 38:168-172.

16. Grimont, P. A. D., M. Y. Popoff, F. Grimont, C. Coynault, and M. Lemelin. 1980. Reproducibility and correlation study of three deoxyribonucleic acid hybridization procedures. Curr. Microbiol. 4:325-330.
17. Hajek, V., W. Ludwig, K. H. Schleifer, N. Springer, W. Zitzelsberger, R. M. Kroppenstedt, and M. Kocur. 1992. Staphylococcus muscae, a new species isolated from flies. Int. J. Syst. Bacteriol. 42:97-101.

18. Hebert, G. A., and G. A. Hancok. 1985. Synergistic hemolysis exhibited by species of staphylococci. J. Clin. Microbiol. 22: $409-415$.

19. Igimi, S., S. Kawamura, E. Takahashi, and T. Mitsuoka. 1989. Staphylococcus felis, a new species from clinical specimens from cats. Int. J. Syst. Bacteriol. 39:373-377.

20. Igimi, S., E. Takahashi, and T. Mitsuoka. 1990. Staphylococcus schleiferi subsp. coagulans subsp. nov., isolated from the external auditory meatus of dogs with external ear otitis. Int. J. Syst. Bacteriol. 40:409-411.

21. Kloos, W. E., and D. W. Lambe, Jr. 1991. Staphylococcus, p. 222-237. In A. Balows, W. J. Hausler, Jr., K. L. Herrmann, H. D. Isenberg, and H. J. Shadomy (ed.), Manual of clinical microbiology, 5th ed. American Society for Microbiology, Washington, D.C.

22. Kloos, W. E., and K. H. Schleifer. 1975. Isolation and characterization of staphylococci from human skin. II. Descriptions of four new species: Staphylococcus wameri, Staphylococcus capitis, Staphylococcus hominis, and Staphylococcus simulans. Int. J. Syst. Bacteriol. 25:62-79.

23. Kloos, W. E., and K. H. Schleifer. 1986. Genus IV. Staphylococcus Rosenbach 1884, $18^{\mathrm{AL}}$, (Nom. Cons. Opin. $17 \mathrm{Jud}$. Comm. 1958. 153), p. 1013-1035. In P. H. A. Sneath, N. S. Mair, M. E. Sharpe, and J. G. Holt (ed.), Bergey's manual of systematic bacteriology, vol. 2. The Williams \& Wilkins Co., Baltimore.

24. Kloos, W. E., T. G. Tornabene, and K. H. Schleifer. 1974. Isolation and characterization of micrococci from human skin, including two new species: Micrococcus hlae and Micrococcus kristinae. Int. J. Syst. Bacteriol. 24:79-101.

25. Kloos, W. E., and J. F. Wolfshohl. 1991. Staphylococcus cohnii subspecies: Staphylococcus cohnii subsp. cohnii subsp. nov. and Staphylococcus cohnii subsp. urealyticum subsp. nov. Int. J. Syst. Bacteriol. 41:284-289.

26. Lachica, R. V. F., P. D. Hoeprich, and C. Genigeorgis. 1972. Metachromatic agar-diffusion microslide technique for detecting staphylococcal nuclease in foods. Appl. Microbiol. 23:168169.

27. Lindsay, J. A., and T. V. Riley. 1991. Susceptibility to desferrioxamine: a new test for the identification of Staphylococcus epidermidis. J. Med. Microbiol. 35:45-48.

28. Maidhof, H., B. Reinicke, P. Blümel, B. Berger-Bächi, and H. Labischinski. 1991. fem $A$, which encodes a factor essential for expression of methicillin resistance, affects glycine content of peptidoglycan in methicillin-resistant and methicillin-susceptible Staphylococcus aureus strains. J. Bacteriol. 173:35073513.

29. Owen, R. J., L. R. Hill, and S. P. Lapage. 1969. Determination of DNA base compositions from melting profiles in dilute buffers. Biopolymers 7:503-516.

30. Schleifer, K. H., W. P. Hammes, and O. Kandler. 1976. Effects of endogenous and exogenous factors on the primary structure of bacterial peptidoglycan. Adv. Microb. Physiol. 13:245-292.

31. Schleifer, K. H., R. Kilpper-Bälz, and L. A. Devriese. 1984. Staphylococcus arlettae sp. nov., $S$. equorum sp. nov. and $S$. kloosii sp. nov.: three new coagulase-negative, novobiocinresistant species from animals. Syst. Appl. Microbiol. 5:501509.

32. Schleifer, K. H., and W. E. Kloos. 1975. Isolation and characterization of staphylococci from human skin. I. Amended descriptions of Staphylococcus epidermidis and Staphylococcus saprophyticus and descriptions of three new species: Staphylococcus cohnii, Staphylococcus haemolyticus, and Staphylococcus xylosus. Int. J. Syst. Bacteriol. 25:50-61.

33. Schleifer, K. H., and M. Kocur. 1973. Classification of staphylococci based on chemical and biochemical properties. Arch. Mikrobiol. 93:65-85.

34. Schleifer, K. H., and R. M. Kroppenstedt. 1990. Chemical and molecular classification of staphylococci. J. Appl. Bacteriol. 
Symp. Suppl. 19:9S-24S.

35. Smith, R. F., and C. L. Bettge. 1972. Comparative characteristics of human and porcine staphylococci and their differentiation in burn xenografting procedures. Appl. Microbiol. 24:929932.

36. Varaldo, P. E., R. Kilpper-Bälz, F. Biavasco, G. Satta, and K. H. Schleifer. 1988. Staphylococcus delphini sp. nov., a coagulase-positive species isolated from dolphins. Int. J. Syst.
Bacteriol. 38:436-439.

37. White, D. G., R. J. Harmon, and B. E. Langlois. 1990. Fluorogenic assay for differentiating Staphylococcus warneri and Staphylococcus hominis strains of bovine origin. J. Clin. Microbiol. 28:602.

38. Zygmunt, W. A., H. P. Browder, and P. A. Tavormina. 1967. Lytic action of lysostaphin on susceptible and resistant strains of Staphylococcus aureus. Can. J. Microbiol. 13:845-853. 